\title{
Effect of a galactomannan coating on mango postharvest physicochemical quality parameters and physiology
}

\author{
Roseane P. AGUiAR ${ }^{1}$, Maria Raquel A. MIRANDA ${ }^{2}$, Álvaro M. P. LIMA ${ }^{2}$, José L. MoscA ${ }^{3}$, Renato A. MoREIRA ${ }^{2}$, Joaquim ENÉAS-FILHo ${ }^{2}$
}

${ }^{1}$ Dep. Agron. Fitotec., Fed. Univ. Ceará, CEP 60455-900, Fortaleza-CE, Brazil roseprocopio@yahoo.com.br

2 Dep. Biochem. Mol. Biol., Fed. Univ. Ceará, CEP 60455-900,

Fortaleza-CE, Brazil rmiranda@ufc.br

3 Embrapa Agroind. Trop., CEP 60511-510,

Fortaleza-CE, Brazil mosca@cnpat.embrapa.

${ }^{*}$ Correspondence and reprints

Received 12 July 2010 Accepted 6 October 2010

Fruits, 2011, vol. 66, p. 269-278 (C) 2011 Cirad/EDP Sciences All rights reserved DOI: 10.1051/fruits/2011034 www.fruits-journal.org

RESUMEN ESPAÑOL, p. 278

\section{Effect of a galactomannan coating on mango postharvest physicochemical quality parameters and physiology.}

Abstract - Introduction. Films act as semi-permeable gaseous barriers capable of maintaining fruit postharvest quality; thus coatings consisting of non-traditional sources may represent an alternative tool for producers. The objective of our work was to investigate the effect of a galactomannan coating on postharvest quality and physiology of 'Tommy Atkins' mangoes. Materials and methods. Physiologically mature mangoes were divided into four lots and stored for $16 \mathrm{~d}$. Control uncoated fruits (lot 1 ) were stored at ambient temperature $\left(25^{\circ} \mathrm{C}\right.$ ), the second lot was uncoated and refrigerated $\left(14^{\circ} \mathrm{C}\right)$, the third lot was coated and stored at ambient temperature, and the fourth lot was coated and refrigerated. Fruit were analyzed for physicochemical quality parameters, antioxidant enzymatic activity and lipid peroxidation. Results and discussion. Control fruit (lot 1) lost almost twice the weight of uncoated refrigerated (lot 2) and coated mangoes at both temperatures (lots 3 and 4); the fruit of lot 1 softened faster. Regarding the antioxidant enzymes, the activity of superoxide dismutase decreased throughout storage without statistical differences between treatments and catalasic activity was significantly inhibited under refrigeration. At ambient temperature, coating delayed the catalasic activity peak to day 12 , which was coincident with the lowest lipid peroxidation degree, evidencing the association of free radical production and scavenging mechanisms. The galactomannan coating was efficient in reducing weight loss and delaying softening; thus, it maintained quality of 'Tommy Atkins' mangoes for a longer period of time than the control treatment during storage at ambient temperature. Refrigeration $\left(14{ }^{\circ} \mathrm{C}\right)$ enhanced the performance of the galactomannan coating; it was effective in slowing down the metabolism and delaying softening to day 12 .

Brazil / Mangifera indica / fruits / storage / postharvest technology / coating / refrigeration / antioxidants / keeping quality / quality

Effet d'un enrobage de galactomannane sur les paramètres de qualité physico-chimique et la physiologie de la mangue en post-récolte.

Résumé - Introduction. Les films agissent comme des barrières gazeuses semi-perméables capables de maintenir la qualité après récolte des fruits, ainsi un enrobage de type non traditionnel pourrait présenter un attrait pour les producteurs. L'objectif de notre travail a été d'étudier l'effet du revêtement de galactomannane sur la qualité post-récolte et la physiologie de mangues 'Tommy Atkins'. Matériel et méthodes. Des fruits physiologiquement mûrs ont été divisés en quatre lots et stockés pendant $16 \mathrm{j}$. Des fruits témoins non traités ont été entreposés à température ambiante $\left(25^{\circ} \mathrm{C}\right)$; un deuxième lot de fruits non traités a été réfrigéré $\left(14^{\circ} \mathrm{C}\right)$; un troisième lot a été enrobé de galactomannane et stocké à température ambiante ; le quatrième lot a été enrobé et réfrigéré. Les fruits ont été analysés à partir de certains paramètres de leur qualité physico-chimique, ainsi que pour leur activité enzymatique antioxydante et pour la peroxydation des lipides. Résultats et discussion. Les mangues du lot témoin (lot 1) ont perdu près de la moitié du poids des mangues du lot non traité et réfrigéré (lot 2) et de celui des mangues des lots traités (lots 3 et 4). Ces fruits du lot 1 se sont ramollis plus rapidement. Pour les enzymes antioxydants, l'activité de la dismutase superoxyde a diminué au cours du stockage sans différence statistique entre les traitements et l'activité catalasique a été significativement inhibée en conditions réfrigérées. À température ambiante, l'enrobage a retardé le pic d'activité catalasique au jour 12 qui lui-même a coïncidé avec le degré de peroxydation lipidique le plus bas, ce qui attesterait de l'association d'une production de radicaux libres avec des mécanismes de piégeage. L'enrobage de galactomannane a été efficace pour diminuer la perte de poids et il a retardé le ramollissement du fruit ; ainsi, pendant la période d'entreposage, il a permis de maintenir la qualité des mangues Tommy Atkins plus longtemps que ne l'a fait le traitement témoin. La réfrigération $\left(14^{\circ} \mathrm{C}\right)$ a amélioré la performance de l'enrobage de galactomannane. Elle a été efficace en ralentissant le métabolisme et en retardant le ramollissement jusqu'au douzième jour.

Brésil / Mangifera indica / fruits / stockage / technologie après récolte / enrobage / réfrigération / antioxydant / aptitude à la conservation / qualité 


\section{Introduction}

Mango is one of the most appreciated fruits of tropical origin, being currently cultivated in all countries of the tropical equatorial zone of the world. In 2008, Brazil was responsible for the production of $1,154,649 \mathrm{t}$ in an area of 74,000 ha and was the second main exporter [1]. In ambient conditions, mangoes have a short mean storage life of $8 \mathrm{~d}$ and the main postharvest technologies used are refrigeration and/or controlled storage atmosphere [2].

When fruits are harvested, an interruption in the gaseous balance with a high influx of oxygen and a proportional loss of carbon dioxide increases the respiration rate, giving rise to excessive intracellular reactive oxygen species, which leads to metabolic losses and, eventually, to senescence [3]. Components of the antioxidant system, such as the enzymes catalase and superoxide dismutase, are responsible for scavenging reactive oxygen species, which are normal byproducts of electron transport chains of respiration and photosynthesis. An imbalance between the production of reactive oxygen species and the ability of antioxidants to neutralize them occurs as part of natural phenomena such as fruit ripening and senescence [4]. The oxidative stress is imposed as reactive oxygen species, superoxide $\left(\mathrm{O}_{2}^{-}\right)$and hydrogen peroxide $\left(\mathrm{H}_{2} \mathrm{O}_{2}\right)$ accumulate, resulting in metabolic disorder due to protein and nucleic acid oxidation and lipid peroxidation, which may be used as a maturity or stress indicator [5]. Therefore, whole or processed plant tissue with high antioxidant capacity presents a greater potential for tolerance to abiotic stresses such as cold [6,7] and extension of postharvest storage life [8].

Various coating materials have been investigated due to their ability to modify the internal fruit atmosphere, slowing down respiration and, therefore, ripening and senescence. Several articles demonstrate that coatings consisting of chitosan, starch, alginate and cellulose have reduced gas and water vapor transmission rates and, consequently, slowed down senescence and maintained fruit quality for a longer period, thus extending the postharvest life [9-13].
Coatings act as semi-permeable gaseous barriers capable of maintaining food quality, besides being biodegradable alternative packaging systems with reduced environmental damage [11]. Surface coatings and films may consist of different biological materials besides polysaccharides, such as proteins and lipids. In general, due to their hydrophilic nature, polysaccharide films exhibit limited moisture barrier properties, thereby plasticizers may be incorporated to improve their mechanical characteristics and result in better application and barrier properties [10].

Galactomannans as reserve carbohydrates of albuminous or endospermic seeds participate as protective agents against predators, and in water retention and turgor regulation during seed germination [14]. The physicochemical and conformational properties of the galactomannans are related to the [mannose:galactose] ratio [15]. An edible coating based on a mixture of galactomannans from Adenanthera pavonina seeds was produced and its rheological properties, sub-chronic toxicity, antimicrobial potential and influence on gas transfer rates were studied [1618], although no data was published on its effects on fruit postharvest quality. The film wettability (Ws) was -29.18 for mangoes, fruit with a low energy surface and critical surface tension of $19.5 \mathrm{mN} \cdot \mathrm{m}^{-1}$, the film thickness was approximately $0.5 \times 10^{-4} \mathrm{~m}$ and its water vapor permeability was close to $7 \mathrm{~g} \cdot \mathrm{m}^{-1} \cdot \mathrm{s}^{-1} \cdot \mathrm{Pa}^{-1}$. The same authors reported that the permeabilities of oxygen $\left(\mathrm{O}_{2} \mathrm{P}\right)$ and carbon dioxide $\left(\mathrm{CO}_{2} \mathrm{P}\right)$ were $\left(4.0 \times 10^{-15}\right.$ and $\left.0.2 \times 10^{-15}\right) \mathrm{g} \cdot \mathrm{m}^{-1} \cdot \mathrm{Pa}^{-1} \cdot \mathrm{s}^{-1} \cdot \mathrm{m}^{-2}$, respectively, and that coating reduced $\mathrm{CO}_{2}$ production and $\mathrm{O}_{2}$ consumption by $50 \%$ for apples and by $11 \%$ and $28 \%$, respectively, for mangoes. These results show galactomannan coatings can reduce gas transfer rates and, thus, have the potential to extend the postharvest life of fruits. The optimal composition of edible galactomannan coatings in view of their surface and permeability properties for mangoes was $1.5 \%$ of $A$. pavonina galactomannan and $1.0 \%$ of glycerol [18]. Moreover, the same authors highlighted that galactomannans could be easily extracted from seeds in a fast and cheap way and applied as coatings. 
Thus, our work investigated the effects of a galactomannan coating on postharvest physicochemical and physiological parameters of mangoes cv. 'Tommy Atkins', as a less expensive storage alternative with a potential outcome for shelf-life extension.

\section{Materials and methods}

\subsection{Fruit material and treatments}

The mangoes (Mangifera indica cv. Tommy Atkins) used in our experiment were obtained from a commercial orchard of Finobrasa Company, in Ipanguaçú-RN, Brazil. The fruits were harvested at physiological maturity with a light-green color and selected to insure good uniformity in maturity and size. Mangoes were divided into four lots and were analyzed on the harvest day and every $4 \mathrm{~d}$ up to $16 \mathrm{~d}$. The first lot was kept without coating as control and stored in ambient conditions $\left(25^{\circ} \mathrm{C}\right.$; $89 \%$ R.H.), the second lot was stored without coating and refrigerated at $14^{\circ} \mathrm{C}(81 \%$ R.H.), the third lot was coated with galactomannan and stored in ambient conditions, and the fourth lot was coated with galactomannan solution and refrigerated.

\subsection{Preparation of coating solution}

The coating solution was initially prepared by extraction of galactomannan from Adenanthera pavonina seeds, after the endosperm was separated from the germ and the hull and suspended in ethanol at $70{ }^{\circ} \mathrm{C}$ for $15 \mathrm{~min}$ [18]. The ethanol was decanted and distilled water was added in a proportion of 1:5 (endosperm:water), and the suspension was left to rest for $24 \mathrm{~h}$. Then, water (1:10, suspension:water) was added, mixed for $5 \mathrm{~min}$ and filtered through a nylon net followed by a centrifugation step at 3,800 $\times g$ (Sigma 4K, B. Braun, Germany) for $20 \mathrm{~min}$ at $20^{\circ} \mathrm{C}$. The precipitation of the galactomannan was achieved by adding ethanol to the supernatant at a ratio of 1:2. The ethanol was decanted and the precipitated galactomannan was lyophilized. The coating solution was prepared by dissolving the lyophilized galactomannan in distilled water $(1.5 \% \mathrm{w} / \mathrm{v})$ followed by the addition of the plasticizer glycerol $(1 \% \mathrm{v} / \mathrm{v})$. Mangoes were immersed in the 1.5\%:1\% galactomannan:glycerol coating solution for $1 \mathrm{~min}$ at $25^{\circ} \mathrm{C}$ and were allowed to drip off for $4 \mathrm{~h}$ and then stored as described before in section 2.1.

\subsection{Physicochemical quality parameters}

At each analysis time, whole mangoes were analyzed for weight and firmness loss and then peeled, the pulp homogenized and stored at $-20{ }^{\circ} \mathrm{C}$. The weight loss was determined with a digital balance (BEL, Model Mark 3100, Italy) and was expressed as percent loss in weight based on the initial weight. Fruit firmness was measured on an automatic texture analyzer (Stable Micro Systems ${ }^{\circledR}$, Model TA.XT2i, London, UK) with a 6-mm plunger. Measurements were made at two equidistant points on the equatorial region of whole, unpeeled fruits and results expressed in Newtons $(\mathrm{N})$. Total soluble solids were determined through refractometry [19], using a digital refractometer (ATAGO, Model N1, Kirkland, USA) with automatic temperature compensation. Results were expressed in ${ }^{\circ} \mathrm{Brix}$ (concentration of sucrose $\mathrm{w} / \mathrm{w}$ ). Titrable acidity was determined with $50 \mathrm{~g}$ of pulp blended with $150 \mathrm{~mL}$ distilled water and measured using an automatic titrator (Mettler-Toledo, Model DL12, Columbus, USA); results were expressed as \% of citric acid [19].

\subsection{Antioxidant enzymes and lipid peroxidation analysis}

Lyophilized fruit pulp (0.20 g) was homogenized with a mortar and pestle in $5 \mathrm{~mL}$ of ice-cold extraction buffer (Tris- $\mathrm{HCl} 0.05 \mathrm{M}$, $\mathrm{pH}$ 7). The homogenate was filtered through muslin cloth and centrifuged at 10,000 $\times g$ for $15 \mathrm{~min}$ at $4^{\circ} \mathrm{C}$. The supernatant fraction was used as protein crude extract for enzyme activity assays and all previous steps were carried out at $4{ }^{\circ} \mathrm{C}$. Total catalase (CAT, EC 1.11.1.6) activity was determined by decrease in $\mathrm{H}_{2} \mathrm{O}_{2}$ monitored at $240 \mathrm{~nm}$ on a Spectronic Genesys Spectrophotometer and quantified by its molar extinction coefficient $\left(36 \mathrm{M}^{-1} \cdot \mathrm{cm}^{-1}\right)$. The results were 
Figure 1.

Changes in weight loss of 'Tommy Atkins' mangoes with time (every $4 \mathrm{~d}$ up to $16 \mathrm{~d}$ ) and according to the treatment applied to four lots of fruits at their harvest $(P \leq 0.05)$. expressed as $\mathrm{mmol} \mathrm{H}_{2} \mathrm{O}_{2} \cdot \mathrm{min}^{-1} \cdot \mathrm{g}^{-1}$ dry matter (DM) [20]. Total superoxide dismutase (SOD, EC 1.15.1.1) activity was determined spectrophotometrically based on inhibition of the photochemical reduction of nitroblue tetrazolium chloride (NBT, Sigma) [21]. Absorbance was measured at $560 \mathrm{~nm}$ and one unit of superoxide dismutase activity (UA) was defined as the amount of enzyme required to cause a 50\% reduction in the NBT photo-reduction rate; results were expressed as $\mathrm{UA} \cdot \mathrm{mg}^{-1} \mathrm{DM} \cdot \mathrm{min}^{-1}$.

The lipid peroxidation degree was evaluated through the malondialdehyde (MDA) content using the thiobarbituric acid (TBA) method [22]. Absorbance was measured at $532 \mathrm{~nm}$ and corrected for non-specific turbidity by subtracting the absorbance at $600 \mathrm{~nm}$. After subtracting the non-specific absorbance $\left(\mathrm{Abs}_{600}\right)$, the malondialdehyde concentration was estimated using its molar extinction coefficient of $155 \mathrm{M}^{-1} \cdot \mathrm{cm}^{-1}$, in triplicate and expressed as nmol malondialdehyde $\mathrm{g}^{-1} \mathrm{DM}$.

\subsection{Statistical analysis}

The experiment was conducted as a $(4 \times 5)$ factorial design with treatments defined as the storage conditions [no coating in ambi-

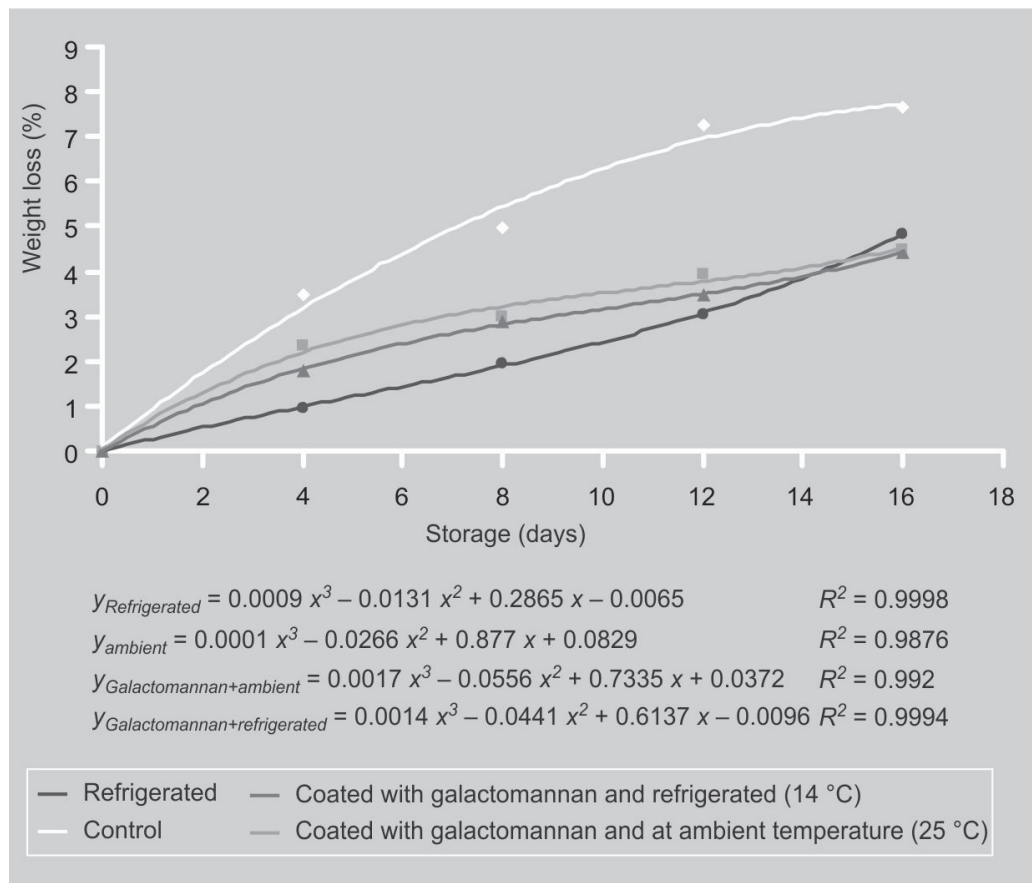

ent conditions (control), no coating under refrigeration, and coated fruit refrigerated and in ambient conditions] and time in storage $[(0,4,8,12$ and 16) d]. The experimental parcels were made up of six fruits, being three repetitions with two fruits each. Statistical analyses were performed using SISVAR software and data was subjected to ANOVA. For physicochemical parameters, in the case of significant interaction between factors, polynomial regressions to $3^{\circ}$ were performed considering those with determination coefficients higher than 0.7 . For the physiological parameters, significant differences were determined by Tukey's test at the 5\% significance level.

\section{Results and discussion}

\subsection{Fruit physicochemical quality analysis}

During storage, mangoes lost weight, with significant differences between treatments (figure 1). At $16 \mathrm{~d}$ of storage, control fruit had the greatest weight loss (7.64\%, $R^{2}=0.98$ ), almost twice the amount of uncoated refrigerated mangoes (4.83\%, $\left.R^{2}=0.99\right)$ and coated fruit $\left(4.4 \%, R^{2}=0.99\right)$ under both temperatures. The high determination coefficients $\left(R^{2} \geq 0.98\right)$ indicate that there is a strong non-linear association between the weight loss (dependent variable) and time in storage, so that over 98\% of the variation in weight loss is explained by the models. After only $4 \mathrm{~d}$, control fruit had lost approximately the same weight as the treated fruits during the total period of storage.

The skin of uncoated fruit offers little protection to moisture loss as the epidermal skin layer and stomata control gas and moisture exchanges between the fruit and the environment. The coating of mangoes also resulted in fruit with better visual appearance (data not shown) and thus greater marketability after storage in both ambient and refrigerated conditions. The galactomannan coating was able to significantly reduce weight loss in ambient conditions when compared with control and this may be 
explained by the water-saturated atmosphere around the fruit leading to a decrease in the water vapor gradient between the fruit surface and the surrounding atmosphere and, as a consequence, to a lower transpiration rate. 'Surpresa' mangoes covered with an edible cassava 3\% starch film were stored at $29{ }^{\circ} \mathrm{C}$ for $12 \mathrm{~d}$ and also presented reduced water loss and improved visual appearance of fruit [13].

The galactomannan coating was significantly efficient in retarding softening under ambient conditions, so that control fruit $\left(24.2 \mathrm{~N}, R^{2}=0.99\right)$ softened faster and were almost twice as soft as coated fruit $(41.7 \mathrm{~N}$, $\left.R^{2}=0.99\right)$ at day 4 , although fruit from both treatments softened to $2.1 \mathrm{~N}$ at the end of the experiment (figure 2). When associated with refrigerated storage conditions, the coating solution was even more efficient in delaying mango softening to $12 \mathrm{~d}$ after harvest $\left(4.59 \mathrm{~N}, R^{2}=0.96\right)$.

In mangoes, firmness loss is an important ripening indicator and is mainly a consequence of cell wall hydrolytic solubilization [23]; thereby, in our study it was observed that coating and storage temperatures were not impediments to the normal ripening process. Modified storage atmospheres with low $\mathrm{O}_{2}$ and high $\mathrm{CO}_{2}$ concentrations help maintain fruit firmness due to a reduction in both cell wall hydrolytic enzyme activity and water loss, besides suppressing chilling injury symptoms [24]. The galactomannan coating used here is able to modify the internal gas composition of mangoes, with a reduction of $11 \%$ in $\mathrm{CO}_{2}$ production and $28 \%$ in $\mathrm{O}_{2}$ consumption [17]. Moreover, these results may also be explained by moisture saturation of the atmosphere close to the fruit surface due to coating, which leads to maintenance of the turgor pressure and contributes to a delay in softening.

The refrigerated mangoes with or without coating presented a statistically higher titrable acidity during storage $\left(R^{2}=0.92\right.$ and $R^{2}=0.91$, respectively), in spite of the slight decrease observed (reaching 0.8\%) when compared with fruit in ambient conditions (titrable acidity of $0.2 \%$ ) (figure 3). This variable is more susceptible to the storage temperature than to coating. Thus, the lower acidity observed for fruit in ambient

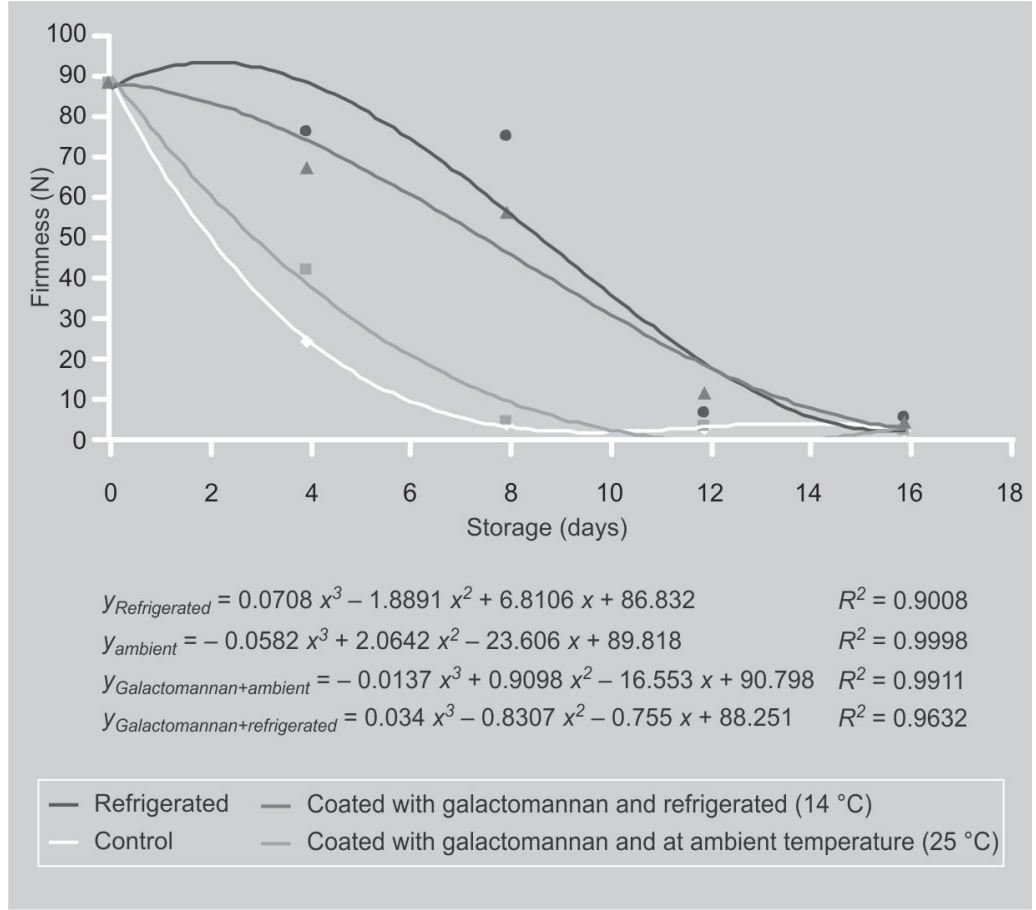

Figure 2.

Changes in firmness of 'Tommy Atkins' mangoes with time (every $4 \mathrm{~d}$ up to $16 \mathrm{~d}$ ) and according to the treatment applied to four lots of fruits at their harvest $(P \leq 0.05)$.

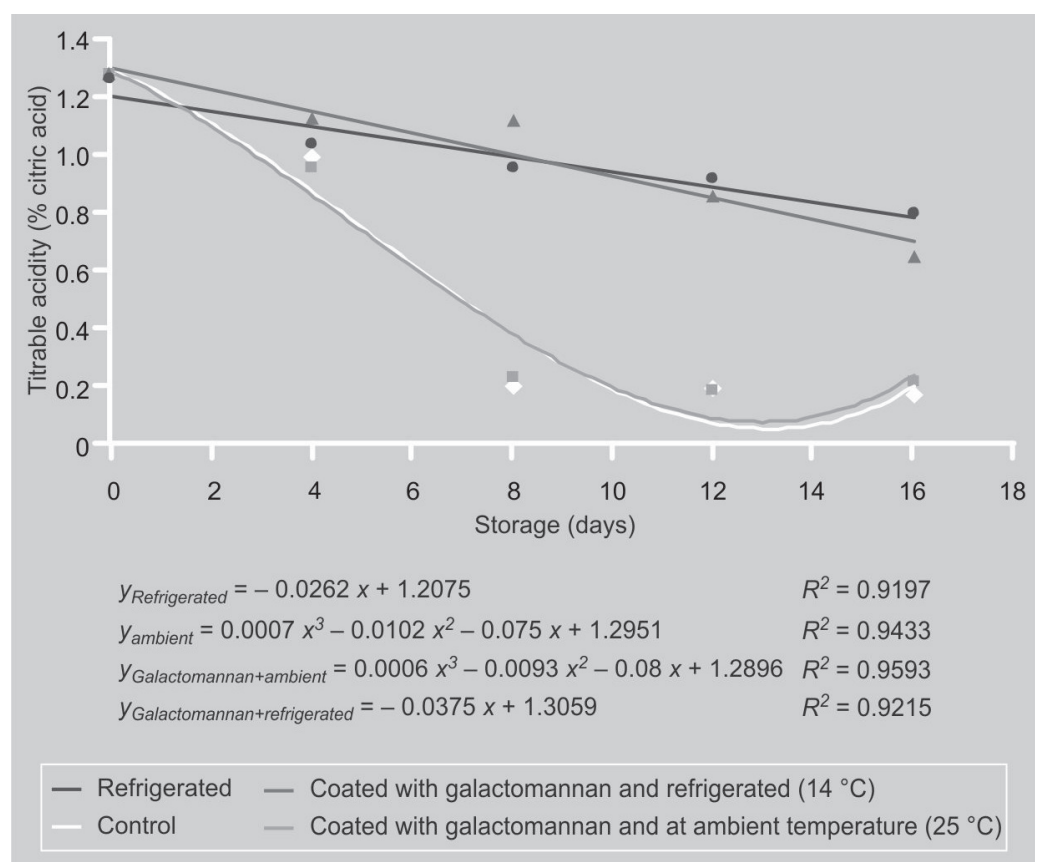

\section{Figure 3.}

Changes in titrable acidity of 'Tommy Atkins' mangoes with time (every 4 d up to $16 \mathrm{~d}$ ) and according to the treatment applied to four lots of fruits at their harvest $(P \leq 0.05)$. 


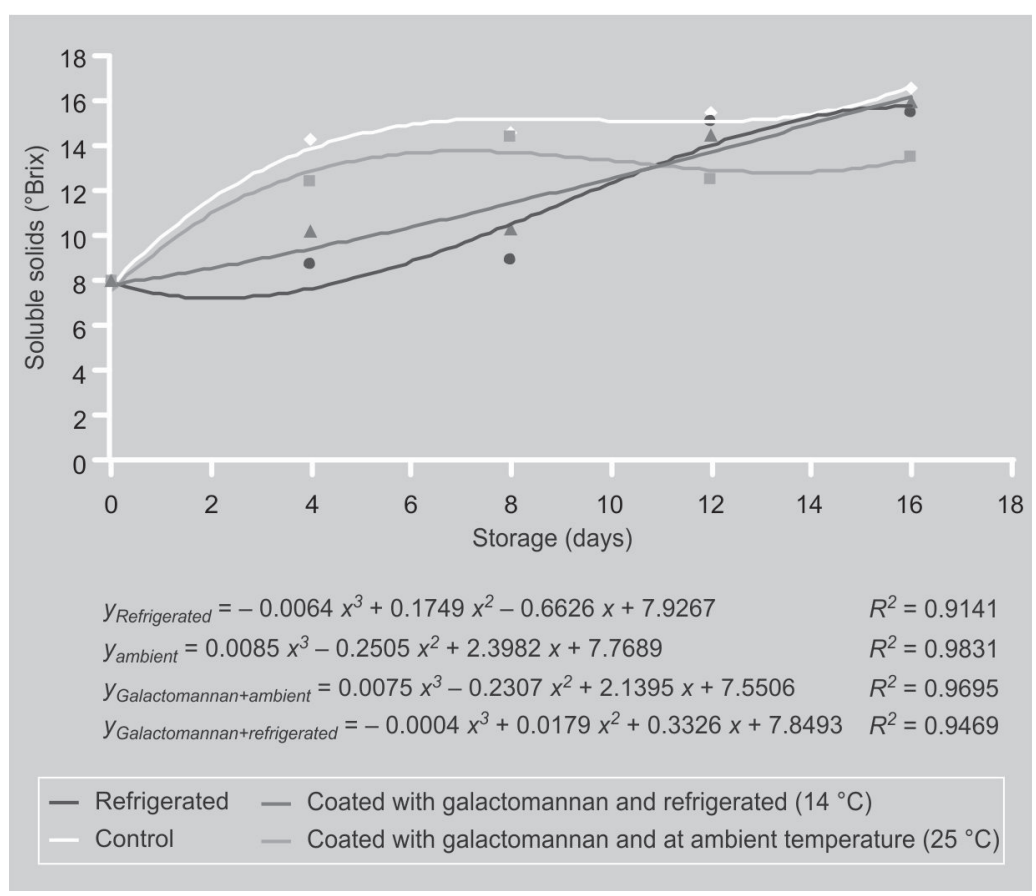

Figure 4. Changes in soluble solids of 'Tommy Atkins' mangoes with time (every $4 \mathrm{~d}$ up to $16 \mathrm{~d}$ ) and according to the treatment applied to four lots of fruits at their harvest $(P \leq 0.05)$. conditions is probably the result of a faster metabolism at the higher storage temperature, leading to a greater use of organic acids as substrates for the respiratory process and demonstrating advancement of ripening. Although mangoes do not usually present high acidity values, this is an important quality parameter, for it may be used as an indicator of metabolic disorders due to stressful conditions, such as chilling temperature. Similar results were reported for pears treated with sodium alginate and methylcellulose coatings and stored at $15^{\circ} \mathrm{C}$ : a slight decrease in titrable acidity with no significant differences was observed between coated and control fruit [12].

The soluble solids content increased for all treatments, with significant differences (figure 4), reaching values considered acceptable for marketing of mangoes [23]. In control, the soluble solids increased faster, reaching $14^{\circ} \mathrm{Brix}\left(R^{2}=0.98\right)$ at day 4 of storage. Meanwhile, the soluble solids content for refrigerated fruit increased more slowly but reached the same values after $12 \mathrm{~d}$ of storage. This result indicates that cold storage was more influential on the metabolic rates of mangoes than the galactomannan coating. During postharvest storage, the soluble solids content increases in fruit, mainly due to polysaccharide depolymerization [25]. Thus, the enzymes involved in this process seem more sensitive to low temperatures than to the internal gas composition modified by the coating. A study on the effect of cold storage and atmosphere modification by plastic films on postharvest conservation of 'Tommy Atkins' mangoes resulted in a similar behavior for soluble solids content, although the values were lower [2].

\subsection{Antioxidant enzymes and lipid peroxidation analysis}

For all treatments, there was a decrease in lipid peroxidation degree, represented by the reduction in malondialdehyde content during the first $8 \mathrm{~d}$ of storage, although refrigerated fruit presented a non-statistically different slower decline (table I). At the end of storage in ambient conditions, the coated fruit had the lowest peroxidation degree, while in control fruit it increased. This increase may be explained by pulp tissue disintegration during fruit senescence, for these fruit were stored in ambient conditions which allowed a fast metabolic rate. Increases in malondialdehyde content are indicatives of membrane lipid peroxidation degree and of cell membrane integrity [25]. For the refrigerated uncoated fruit, the high content of peroxidation products observed at the beginning of storage may result from harvesting stress or acclimation to cold.

Membrane lipids are highly susceptible to oxidation by reactive oxygen species and, during fruit ripening and senescence, there is an accumulation of peroxidation products which result in cell membrane rupture. Thus, ripening and mostly senescence are considered oxidative phenomena due to an increase in reactive oxygen species to toxic levels as a result of a decline in antioxidant scavenging potential. The antioxidant enzymes superoxide dismutase and catalase catalyze the dismutation of $\mathrm{O}_{2}^{-}$into $\mathrm{H}_{2} \mathrm{O}_{2}$ and the decomposition of $\mathrm{H}_{2} \mathrm{O}_{2}$ into water and oxygen, respectively [26]. So, ripe or over-ripe fruit show an imbalance between reactive oxygen species production and scavenging mechanisms, which leads to cell death. Besides natural senescence, stressful 
Table I.

Catalase activity and malondialdehyde content of galactomannan-coated mangoes during postharvest storage under ambient $\left(25^{\circ} \mathrm{C}\right)$ and refrigerated $\left(14^{\circ} \mathrm{C}\right)$ temperatures.

\begin{tabular}{|c|c|c|c|}
\hline Treatment & $\begin{array}{l}\text { Time } \\
\text { (d) }\end{array}$ & $\begin{array}{l}\text { Malondialdehyde content } \\
\qquad\left(\mathrm{nmol} \cdot \mathrm{g}^{-1} \mathrm{DM}\right)\end{array}$ & $\begin{array}{c}\text { Catalase activity } \\
\left(\mu \mathrm{mol} \cdot \mathrm{H}_{2} \mathrm{O}_{2} \cdot \mathrm{min}^{-1} \cdot \mathrm{g}^{-1} \mathrm{DM}\right)\end{array}$ \\
\hline \multirow[t]{5}{*}{ Control } & 0 & $1.533 \mathrm{aA}$ & $4.8 \mathrm{bA}$ \\
\hline & 4 & $0.787 \mathrm{aA}$ & $6.2 \mathrm{bA}$ \\
\hline & 8 & $0.107 \mathrm{bB}$ & $70.1 \mathrm{aA}$ \\
\hline & 12 & $0.954 \mathrm{aA}$ & $39.5 \mathrm{abB}$ \\
\hline & 16 & $1.232 \mathrm{aA}$ & $47.9 \mathrm{abA}$ \\
\hline \multirow{5}{*}{$\begin{array}{l}\text { Coated, stored at ambient } \\
\text { temperature }\end{array}$} & 0 & $1.533 \mathrm{aA}$ & $4.8 \mathrm{bA}$ \\
\hline & 4 & $0.742 \mathrm{aA}$ & $10.4 \mathrm{bA}$ \\
\hline & 8 & $0.154 \mathrm{bB}$ & $56.2 \mathrm{abA}$ \\
\hline & 12 & $0.101 \mathrm{bB}$ & $100.6 \mathrm{aA}$ \\
\hline & 16 & $0.116 \mathrm{bB}$ & $27.0 \mathrm{bB}$ \\
\hline \multirow[t]{5}{*}{ Refrigerated } & 0 & $1.533 \mathrm{aA}$ & $4.8 \mathrm{aA}$ \\
\hline & 4 & $1.548 \mathrm{aA}$ & $2.7 \mathrm{aA}$ \\
\hline & 8 & $1.268 \mathrm{aA}$ & $4.8 \mathrm{aB}$ \\
\hline & 12 & $0.633 \mathrm{aA}$ & $4.8 \mathrm{aC}$ \\
\hline & 16 & $0.993 \mathrm{aA}$ & $11.1 \mathrm{aC}$ \\
\hline \multirow[t]{5}{*}{ Coated and refrigerated } & 0 & $1.533 \mathrm{aA}$ & $4.8 \mathrm{aA}$ \\
\hline & 4 & $0.810 \mathrm{aA}$ & $10.4 \mathrm{aA}$ \\
\hline & 8 & $0.700 \mathrm{aA}$ & $15.9 \mathrm{aB}$ \\
\hline & 12 & $0.937 \mathrm{aA}$ & $9.7 \mathrm{aC}$ \\
\hline & 16 & $0.737 \mathrm{aA}$ & $9.0 \mathrm{aC}$ \\
\hline
\end{tabular}

conditions such as storage under chilling temperatures also lead to accumulation of peroxidation products [8].

The imbalance between reactive oxygen species production and scavenging mechanisms is evident when comparing the results from lipid peroxidation with the activities of catalase (table I). For control, there was a significant increase in catalase activity at day 8 , reaching $70.1 \mathrm{mmol} \mathrm{H}_{2} \mathrm{O}_{2} \cdot \mathrm{min}^{-1} \cdot \mathrm{g}^{-1}$ $\mathrm{DM}$, and then a decline. The coated fruit stored at ambient temperature showed a delayed activity peak at day 12 with $100.6 \mathrm{mmol} \mathrm{H}_{2} \mathrm{O}_{2} \cdot \mathrm{min}^{-1} \cdot \mathrm{g}^{-1} \mathrm{DM}$, coincident with the lowest malondialdehyde content. There was a significant difference after $8 \mathrm{~d}$ of storage between fruits under ambient conditions and refrigeration; the latter had lower activity values as refrigeration inhib- ited catalasic activity in both uncoated and coated mangoes, which showed low and not statistically different activity throughout storage. Both coated and uncoated mangoes showed a faster decline in superoxide dismutase activity under ambient than refrigerated temperature, although without any statistical differences (data not shown).

At ambient temperature, the high catalasic activity observed for coated mangoes after 4 d of storage justifies the low lipid peroxidation degree when compared with control. Thereby, the modified gas transfer atmosphere by the galactomann coating, resulting in lower water vapor, oxygen and carbon dioxide permeabilities, probably exerted an effect on the enzyme activity. Now, the higher levels of lipid peroxidation observed at the beginning of cold storage 
for uncoated fruit are probably a consequence of the accumulation of $\mathrm{H}_{2} \mathrm{O}_{2}$ resulting from the inhibition of catalase activity. Meanwhile, coated refrigerated mangoes presented non-significantly higher levels of catalase activity which possibly offered some antioxidant protection justified by the lower peroxidation degree at the initial $8 \mathrm{~d}$ of storage.

A transient increase in hydrogen peroxide is suggested to activate protective mechanisms as acclimation to chilling and, in accordance with this, it has been reported that incidence of chilling injuries is negatively correlated with $\mathrm{H}_{2} \mathrm{O}_{2}$ endogenous levels in mangoes [25]. The same authors reported that mangoes stored under very low temperature $\left(4^{\circ} \mathrm{C}\right)$ presented an increase in catalase activity throughout storage as a chilling-induced reactive oxygen species protection mechanism. The results indicate that galactomannan coating reduced lipid peroxidation, possibly contributing to a decrease in susceptibility to chilling in spite of the low catalase activity; thus, under the storage conditions tested here, there were no evident chilling injury symptoms, but indeed a non-harmful catalase inhibition.

\section{Conclusions}

The galactomannan coating was efficient in reducing weight loss and delaying softening and thus in maintaining quality of 'Tommy Atkins' mangoes for a longer period of storage at ambient temperature $\left(25^{\circ} \mathrm{C}\right)$. Refrigeration at $14{ }^{\circ} \mathrm{C}$ enhanced the performance of the galactomannan coating and was effective in slowing down the metabolism and delaying softening to day 12 of storage. The activity of the antioxidant enzyme superoxide dismutase declined throughout storage non-significantly; meanwhile, catalasic activity was inhibited by refrigeration and at ambient temperature. The coating delayed the activity peak which was coincident with the lowest lipid peroxidation degree, evidencing the association between reactive oxygen species production and scavenging mechanisms.

\section{Acknowledgments}

We acknowledge Embrapa Agroindústria Tropical and the Conselho Nacional de Desenvolvimento Científico e TecnológicoCNPq/INCT-Frutos Tropicais, Brazil.

\section{References}

[1] Anon., Agricultural database of FAOSTAT Quantity Production - Crops - mango, FAO, 2008, available in www.fao.org (accessed Nov. 2010).

[2] Sousa J.P., Praça E.F., Alves D.E, BezerraNeto F., Dantas F.F., Influence of refrigerated storage and plastic film-modified atmosphere in quality of 'Tommy Atkins' mangoes, Rev. Bras. Frutic. 24 (3) (2002) 665668.

[3] Kluge R.A., Nachtigal J.C., Fachinello J.C., Bilhalva A.B., Postharvest physiology and handling of fruits from temperate climate, Rural Press, Campinas, SP, Brazil, 2002, $163 \mathrm{p}$.

[4] Arora A., Sairam R.K., Srivastava G.C., Oxidative stress and antioxidative system in plants, Current Sci. 82 (2002) 1221-1235.

[5] Jiménez A., Creissen G., Kular B., Firmin J., Robinson S., Verhoeyen M., Mullineaux P., Changes in oxidative processes and components of the antioxidant system during tomato fruit ripening, Planta 214 (2002) 751758.

[6] Janda T., Szalai G., Rios-Gonzalez K., Veisz O., Páldi E., Correlation between frost tolerance and antioxidant activities in cereals, Acta Biol. Szeged. 46 (3-4) (2002) 67-69.

[7] Leja M., Mareczek A., Ben J., Antioxidant properties of two apple cultivars during longterm storage, Food Chem. 80 (2003) 303307.

[8] Lacan D., Baccou J.C., High levels of antioxidants enzymes correlate with delayed senescence in no netted muskmelon fruits, Planta 204 (1998) 377-382.

[9] Eum H.Y., Hwang D.K., Linke M., Lee S.K., Zude M., Influence of edible coating on quality of plum (Prunus salicina Lindl. cv. 'Sapphire'), Eur. Food Res. Technol. 229 (3) (2009) 427-434. 
[10] Li J., Yan J., Wang J., Zhao Y., Cao J., Jiang W., Effects of chitosan coating on oxidative stress in bruised Yali pears (Pyrus bretschneideri Rehd.), Int. J. Food Sci. Technol. 45 (2010) 2149-2154.

[11] Odilio A.B.G., Leon A.M., Edible chitosan films, Rev. Biotecnol. Ciênc. Desenvolv. 30 (2003) 33-38.

[12] Maftoonazad N., Ramaswamy H.S, Marcotte M., Shelf-life extension of peaches through sodium alginate and methyl cellulose edible coatings, Int. J. Food Sci. Technol. 43 (2008) 951-957.

[13] Scanavaca L. Jr., Fonseca N., Pereira M.E.C., Use of cassava starch in the 'surpresa' mango postharvest, Rev. Bras. Frutic. 29 (1) (2007) 67-71.

[14] Anulov O.V., Smirnova N.I., Mestechkina N.M., Shcerbukhin V.D., Content and composition of non-starch water-soluble polysaccharides in seeds of some Fabaceae, Russ. J. Plant Physiol. 45 (6) (1998) 802-804.

[15] Cerqueira M.A., Lima A.M.P., Teixeira J.A., Moreira R.A., Vicente A.A., Suitability of novel galactomannans as edible coatings for tropical fruits, J. Food Eng. 94 (2009) 372378.

[16] Martins J.T., Cerqueira M.A., Souza B.W.S., Shelf life extension of ricotta cheese using coatings of galactomannans from nonconventional sources incorporating nisin against Listeria monocytogenes, J. Agric. Food Chem. 58 (3) (2010) 1884-1891.

[17] Lima A.M.P., Cerqueira M.A., Souza B.W.S., Santos E.C.M., Teixeira J.A., Moreira R.A., Vicente A.A., New edible coating composed of galactomannan on collagen blends improve fruit quality - Influence on fruits gas transfer rate, J. Food Eng. 97 (1) (2010) 101109.

[18] Cerqueira M.A., Pinheiro A.C., Souza B.W.S., Lima A.M.P., Ribeiro C., Miranda C., Teixeira
J.A., Moreira R.A., Coimbra M.A., Gonçalves M.P., Vicente A.A., Extraction, purification and characterization of galactomannans from non-traditional sources, Carbohydr. Polym. 75(3) (2009) 408-414.

[19] Anon., Official methods of analysis of the association of official analytical chemistry, AOAC, Wash. Press, U.S.A., 2005.

[20] Beers R.F. Jr., Sizer I.W., A spectrophotometric method for measuring the breakdown of hydrogen peroxide by catalase, J. Biol. Chem. 195 (1952) 133-140.

[21] Giannopolitis C.N., Ries S.K., Superoxide dismutase. I. Occurrence in higher plants, Plant Physiol. 59 (1977) 309-314.

[22] Heath R.L., Packer L., Photoperoxidation in isolated chloroplasts. I. Kinetics and stoichiometry of fatty acids peroxidation, Arch. Biochem. Biophys. 125 (1968) 189-198.

[23] Alves R.E., Filgueiras H.A.C., Pereira M.E.C., Cocozza F.D.M., Jorge J.T., Postharvest maturation of 'Tommy Atkins' at two stages of maturity and treated with 1-MCP, Acta Hortic. 645 (2004) 627-632.

[24] Ali Z.M., Chin L., Marimuthu M., Lazan H., Low temperature storage and modified atmosphere packaging of carambola fruit and their effects on ripening related texture changes, wall modification and chilling injury symptoms, Postharvest Biol. Technol. 33 (2) (2004) 181-192.

[25] Wang B., Wang J., Liang H., Yi J., Zhang J., Lin L., Wu Y., Feng X., Cao J., Jiang W., Reduced chilling injury in mango fruit by $2,4-$ dichlorophenoxyacetic acid and the antioxidant response, Postharvest Biol. Technol. 48 (2) (2008) 172-181.

[26] Huang R., Xia R., Hu L., Lu Y., Wang M., Antioxidant activity and oxygen-scavenging system in orange pulp during fruit ripening and maturation, Sci. Hortic. 113 (2) (2007) 166-172. 
Efecto de un revestimiento de galactomanano en los parámetros de calidad físico-químico y la fisiología del mango en postcosecha.

Resumen - Introducción. Los films actúan como barreras gaseosas semipermeables, capaces de mantener la calidad postcosecha de los frutos; de este modo, un revestimiento de tipo nuevo podría ser una atracción para los productores. El objetivo de nuestro trabajo fue estudiar el efecto del revestimiento de galactomanano en la calidad postcosecha y en la fisiología de mangos 'Tommy Atkins'. Material y métodos. Se dividieron frutos fisiológicamente maduros en cuatro lotes y almacenados durante $16 \mathrm{~d}$. Los frutos testigo no tratados se depositaron en almacén a temperatura ambiente $\left(25^{\circ} \mathrm{C}\right)$; un segundo lote no tratado se refrigeró $\left(14^{\circ} \mathrm{C}\right)$; un tercer lote se revistió de galactomanano y fue almacenado a temperatura ambiente; el cuarto lote se revistió y refrigeró. Se analizaron los frutos, a partir de ciertos parámetros de su calidad físico-química, y respecto a su actividad enzimática antioxidante y a la perodixación de los lípidos. Resultados y discusión. Los mangos del lote testigo (lote 1) perdieron cerca de la mitad del peso respecto a (lote 2) - mangos del lote no tratado y refrigerado - y a (lotes 3 y 4) - los lotes tratados. Los frutos del lote 1 se reblandecieron más rápidamente. Para las encimas antioxidantes, la actividad del superóxido dismutasa disminuyó en el curso del almacenamiento, sin diferencia estadística entre los tratamientos; y la actividad catalística se inhibió considerablemente en condiciones refrigeradas. A temperatura ambiente, el revestimiento retrasó el pico de la actividad catalística al día 12, que coincidió con el grado más bajo de perodixación lipídica, lo que podría demostrar la asociación de una producción de radicales libres con mecanismos de captación. El revestimiento de galactomanano fue eficaz para disminuir la pérdida de peso y retrasó el reblandecimiento del fruto. De este modo, durante el periodo de almacenamiento, permitió guardar la calidad de los mangos Tommy Atkins durante más tiempo que el tratamiento testigo. La refrigeración $\left(14^{\circ} \mathrm{C}\right)$ mejoró el rendimiento del revestimiento de galactomanano. Fue eficaz, ya que ralentizó el metabolismo y retrasó el reblandecimiento hasta el duodécimo día.

Brasil / Mangifera indica / frutas / almacenamiento / tecnología postcosecha / revestimiento / refrigeración / antioxidantes / aptitud para la conservación / calidad 